\title{
Ilomata International Journal of Management
}

P-ISSN: 2714-8971; E-ISSN: 2714-8963

Volume. 2 Issue 4 October 2021

Page No: 319-326

\section{The Impact of Covid-19 on the Development of Various Business Sectors}

\author{
Sunarmin ${ }^{1}$, Ahmad Junaidi ${ }^{2}$, Endah Fantini ${ }^{3}$ \\ ${ }^{123}$ Institut Ilmu Sosial dan Manajemen STIAMI \\ Correspondent: sunarmin3@gmail.com
}

$\begin{array}{ll}\text { Received } & \text { : July 28, } 2021 \\ \text { Accepted } & \text { : August 25,2021 } \\ \text { Published } & \text { : October 31, } 2021\end{array}$

Citation: Sunarmin., Junaidi, A., Fantini, E. (2021). The Impact of Covid-19 on the Development of Various Business Sectors. Ilomata International Journal of Management, 2(4), 319-326. https://doi.org/10.52728/ijim.v2i4.387
ABSTRACT: Outbreaks of the new corona virus or Corona Virus Disease 2019 (Covid-19) are increasingly felt in the domestic economy, especially in terms of consumption, corporate, financial sector, and Micro, Small and Medium Enterprises (MSMEs). The existence of Large-Scale Social Restrictions (PSBB) that has been declared by the government most of the activities involving the public are restricted, such as offices or offices that are closed, restrictions on religious activities and restrictions on public transportation. The business world has not been separated from the shadows of the Corona Covid-19 pandemic. Instead of diminishing, some countries have confirmed that they will experience a second wave of pandemic that began in Wuhan, China. The purpose of this study is to find out whether the impact of Covid-19 will have a widespread effect on business entities and the sustainability of business entities. This research is a descriptive study, using the literature method where research conducted by studying and collecting data from libraries related to tools, both in the form of journals and scientific studies of research that has been published in public journals. The results of the study concluded that the impact on Covid-19 had a significant influence on the development of the business world. The biggest influences occur in the mall/supermarket, hospitality, manufacturing and various businesses related to the use of mass labor. In this study, not many scientific writers have focused on examining the impact of this 19 on the business world in general. Although the fact in the field of influence of Covid-19 is clearly seen the fact in the life of the wider community due to many businesses limit / lay off and even deduct workers' income from the value of income received.

Keywords: Business, Covid-19, PSBB, UMKM

\section{INTRODUCTION}

Since the beginning of 2020, the COVID-19 has spread worldwide at an alarming rate causing many threats to sustainable development of the business sector. The decline in consumer demand has hugely impacted service industries, such as wholesale and retail sales, tourism (Chen, et. al, 2021). This virus is still associated with the cause of SARS and MERS which had erupted a few years ago. The world of global health has recently been stirred up with news about the corona virus that continues to spread, not only in China but also in other countries. This has 
kept health researchers from various countries busy, researching and further studying the corona virus to determine the right effort or next step (Luo, 2021; Videon et al., 2021).

For preliminary information, the scale of an epidemic depends on how quickly and easily the virus is transmitted from person to person. Meanwhile, research on the corona virus has only just begun. Scientists estimate that anyone who has contracted the corona virus can infect between 1.5 and 3.5 others without proper control. Until now there is no known cause of the Corona virus, but it is known that this virus is spread by animals and is capable of transmitting from one species to another, including humans (Nebolsina, 2021).

Corona virus is known to originate from Wuhan City in China and appeared in December 2019. Based on research, the danger of Corona virus can cause death. In fact, infected and cured patients will experience permanent damage to the lungs and antibodies. The number of corona virus positive cases (Covid-19) in Indonesia rose to seventh in the Asian region. According to Johns Hopkins University School of Medicine, Covid-19 positive cases in Indonesia were 111,455 cases. Of that amount 68,975 people were recovered, and 5,236 patients died. Qatar to date has recorded 111,107 positive cases of Covid-19, with 177 patients dying and 107,779 recovering (Burhanuddin \& Abdi, 2020).

Countries in the Asian region with the highest number of Covid-19 cases are still occupied by India with $1,750,723$ cases. Of that number 1,145,629 patients recovered and 37,364 people died. Position after India occupied by Iran with 309,437 cases, 268,102 people recovered and 17,190 patients died. While Pakistan is in third place with 279,699 cases, 248,577 patients recovered and 5,976 people died. The Covid-19 case in Saudi Arabia is fourth in Asia with 278,835 cases, 240,081 patients recovered and 2,917 people died. The fifth position is occupied by Bangladesh with 240,746 positive cases, 136,839 patients recovered and 3,154 people died. Iraq came in sixth place with 129,151 positive cases, 91,886 patients recovered and 4,868 people died.

In the United States, the Center for Disease Control and Prevention (CDC) in its weekly report in April released a study of the characteristics of health workers affected by COVID-19. From 12 February to 9 April it was announced that there were 9,282 (19\% of 49,370 reporting written jobs) health workers infected with the corona virus. The data is also quite detailed: the average age of death, sex, the percentage of those who come in contact with patients in the hospital, and the general symptoms of corona virus infection that afflict health workers. In Italy, open data includes reporting on the number of health workers infected with the corona virus, indicating infection in the medical community reaches $10 \%$. Spain reports infections in health workers reaching 20\%. In Malaysia, the government has reported that $5.8 \%$ of positive cases are health workers. Globally, the International Council of Nurses noted that as of 5 May, more than 90,000 health workers in the world were infected with Covid-19, and even predicted to be more. Their risk of contracting the virus is very high because every day they interact in close proximity with COVID patients and people who seek treatment who may carry the corona virus. Moreover, the virus incubation period is quite long, 2-14 days (Meyer et al., 2021).

This study will hopefully contribute towards the creation of effective support mechanisms through associated entrepreneurial development organizations for micro-entrepreneurs to thrive during and after a crisis (Fabeil et al., 2020).

The Food and Beverage Sector Education and Training Authority is responsible for skills development in the Food and Beverages (FoodBev) Manufacturing Sector in South Africa and seeks to quantify Foodbev sustainability (Telukdarie et al., 2020).

Change in business orientations, working and living conditions necessitates a review of planning, project development, marketing strategies, use and management processes of settlements (Carracedo et al., 2021; Tanrivermiş, 2020).

We analyzed the sharing economy sector mainly from the perspektif of four stakeholders: sharing economy firms, service providers, service receivers (customers), and regulatory bodies (Hossain, 2021; Meyer et al., 2021). 


\section{METHOD}

In this study, data on macro-economic change and the real estate sector as secondary data were used to provide the base of analysis and generalization of the prevailing situation. Due to the prevailing situation, during and after the pandemic, which prohibits the smooth carrying out of physical in particular, the evaluation and collection of data were mainly done though the reviews of the contents on the main stream news and media, advertisement, comments and through this possible effects of the pandemic impacts in the business sector have revealed.

\section{RESULTS AND DISCUSSION Spread Of Covid-19 (Corona Virus)}

The Covid-19 case, which became a trend in early 2020, included a type of disease that can spread quickly. Because this disease can spread through the air, so do not be surprised if this virus is a world disease. The spread of this virus indiscriminately, both old, young and children. The WHO World Organization recommends protective procedures against aerosol spread of the corona virus or COVID-19. This procedure is applied in health facilities that handle cases of corona virus or COVID-19. Aerosols refer to solid or liquid particles in air or other gases. These particles float before landing on the target surface. How to spread the corona virus COVID-19 is through droplets or vomiting (fomites), in close, unprotected contact. Corona virus transmission or COVID-19 occurs between those who have been infected with people without disease pathogens. In various cases in Indonesia the spread of this virus has many effects on nurses and doctors who handle the case directly. Globally, as of May 6, 2020 there were over 3.58 million positive cases of COVID-19 with 247,503 deaths (Case Fatality Rate 6.9\%). As of May 7, 989 health workers worldwide died from Covid-19 or 0.37\% (989 / 270,426).

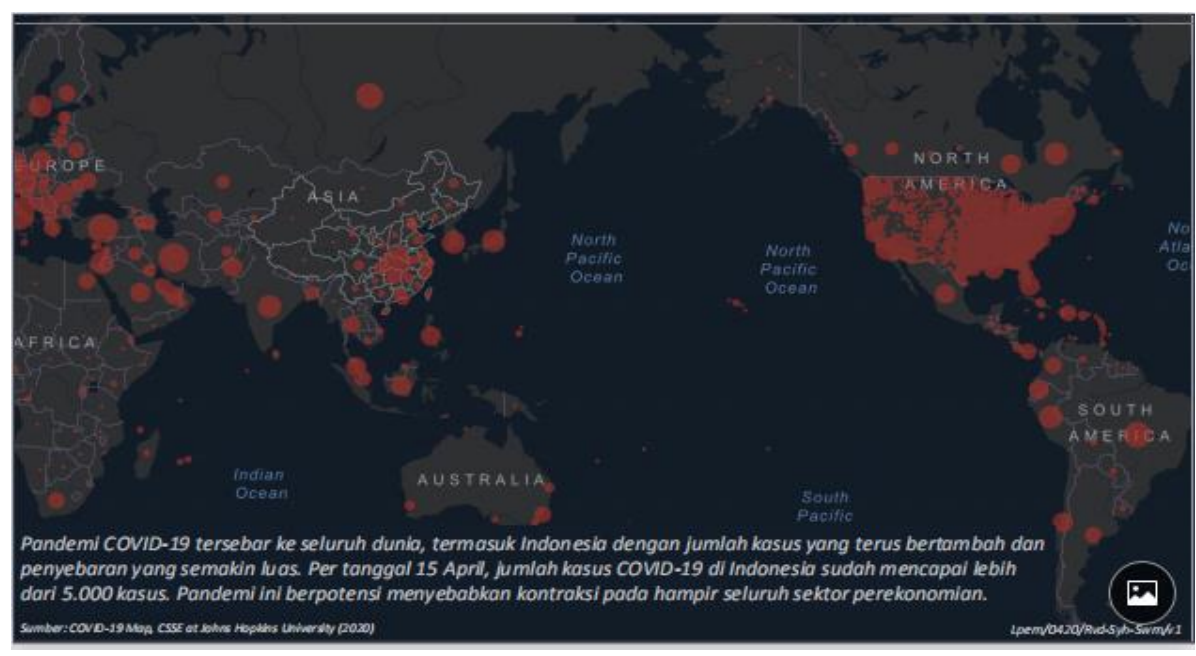

Source : Covid-19 Map, CSSE of Johns Hopkins University 2020

In Indonesia in the same period, there were around 12,400 positive cases with 895 deaths (CFR $7.2 \%$ ), including 55 health workers. This means that in every 100 deaths there are 6-7 health workers $(55 / 895)$ who die. If the situation does not change, namely the percentage of deaths of health workers and doubling of Indonesia's death cases per 23 days, then in early June the number of health workers who died could touch 100 people. This is very worrying, because the percentage of health worker deaths in Indonesia today $(6.5 \%)$ is far higher than the global average $(0.37 \%)$. Even the number in Indonesia is far higher than the United States which has the highest number of cumulative deaths in the world today.

The US Center for Disease Control and Prevention Study reports that the percentage of deaths of health workers in the country as of April 9 was $0.16 \%$ (27 deaths of health workers per 16,570 total deaths from Covid-19). In the UK, one of the countries in Europe which has a high 
mortality rate, as of 2 May, the percentage of deaths of health workers was $0.5 \%$ (165 deaths of health workers per 28,131 of all deaths due to Covid-19). Various ways The spread of the COVID-19 corona virus, including through the toilet seat, bathroom door handle, and sink (fecal shedding) occurs in some patients. However, the spread of corona virus or COVID-19 or COVID-19 with fecal shedding, until now is not a major transmission effort. In addition to the spread, in its report WHO also wrote how to prevent the COVID-19 corona virus. The most important prevention is to wash your hands frequently and cover your mouth and nose when sneezing or coughing. Washing hands and covering mouth and nose when coughing or sneezing should be done as often as possible to deal with the corona virus COVID-19. Another preventive measure is to keep your distance from other community members. With a distance of one meter, the risk of contracting the corona virus COVID-19 can be suppressed. In addition, each member of the community must be prepared to help the elderly who are more susceptible to corona virus infection or COVID-19 (Hidayat et al., 2012; Rahmanti et al., 2021).

\section{EFFECT OF COVID-19 ON DEVELOPMENT OF BUSINESS}

Corona virus outbreaks have affected the daily lives of Indonesian people. Nowadays fewer and fewer people are traveling out of the house since the government is advocating to do all activities from home. Of course there are many things that affect business in times like this. One reason is: consumers rarely go out, only shop as needed, and make various transactions via online. In addition, social restrictions also cause various business activities to be done remotely. Thus, many workers have to work from home (work from home). In the field of education, it also had a significant impact.

There are several obstacles experienced by students, teachers and parents in online teaching and learning activities, namely lack of technology mastery, internet quota costs added, there are additional jobs for parents in assisting children learning, communication and socialization between students, teachers and parents becomes reduced and working hours become unlimited for teachers because they have to communicate and coordinate with parents, other teachers and school principals (Purwanto et al., 2020). Media revenues dropped dramatically due to the Covid-19 corona virus pandemic. The pandemic that occurred in early 2020 paralyzed the wheels of the Indonesian economy. Impact, companies cut advertising spending in the media. This affects the media business. The condition of the Covid-19 pandemic has worsened the sustainability of print media, which has now been eroded by online media. Looking at economic development and influence is not only limited to the scope of the economy itself. But the economy can also be affected by culture and health. This is evidenced by the spread of the Corona virus also has a negative impact on the world economy (Burhanuddin \& Abdi, 2020).

The government does not yet have a post Covid-19 strategy. The government continues to bring forth a new normal life narrative, but does not see a strategy. The private sector sees the strategy taken by the government. The private sector sees strategies prepared by the government and the state after co-19. According to the results of data processing, shows that there is a tendency of a positive relationship between the number of Covid-19 cases and the strength of the exchange

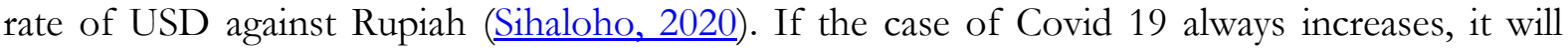
worsen the condition of the Indonesian economy. One indicator is the weakening of the Rupiah against the USD and other foreign currencies. Another economic impact is the movement of the JCI which is in free fall. JCI data shows that before there was a Covid-19 case in Indonesia, the JCI value was in the range of 6000's, but after there was Covid-19 in Indonesia, the JCI value fell freely to the range of 4000s. The European Union already has a strategy to drive the wheels of the economy post Covid-19. The European Union is investing 875 billion euros to rebuild the industry. So that Europe can survive independently, especially wanting to reduce dependence on Chinese products, and will propose investments in environmentally friendly industries. The hotel and tourism industry is a complete package that always goes hand in hand. 


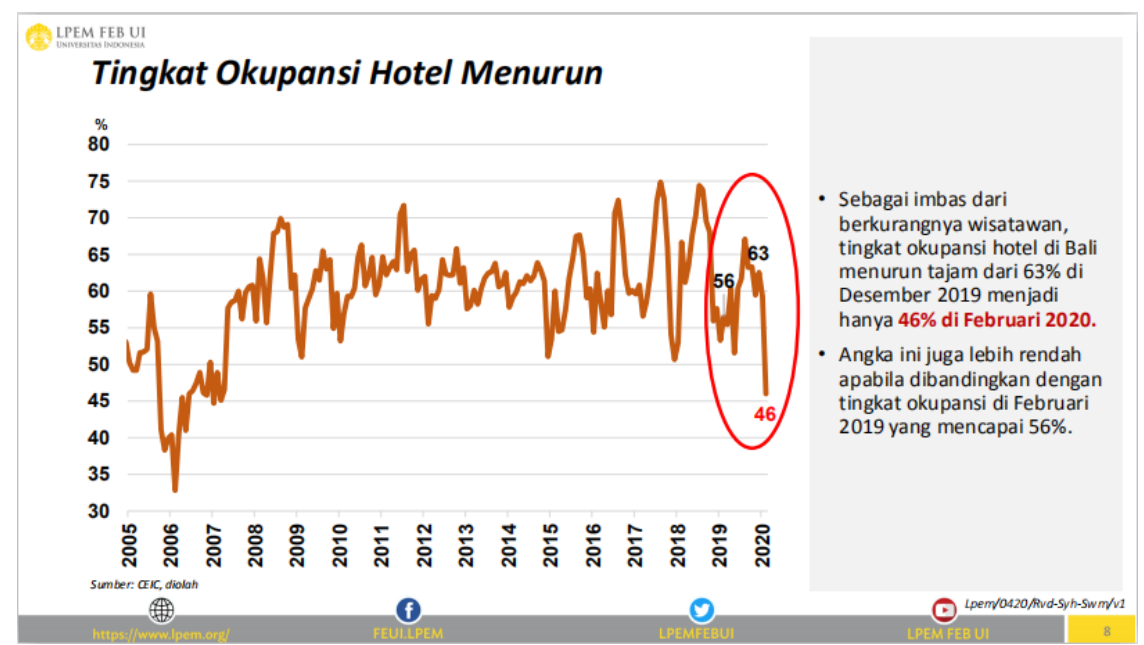

Source : CEIC, diolah (Pusat Kajian Iklim Usaha dan GVC - LPEM FEB UI, April 2020)

During the Corona virus pandemic, people are required to limit outdoor activities, even some countries 'force' to quarantine their population with a lockdown policy. Impact, some tourist attractions must be closed due to no visitors. This applies to the hotel sector. Even for the sake of survival, some hotels are desperate to change their business concept by offering a quarantine package for those who are being monitored. Not much different from the tourism and hotel sectors, the aviation business also lost money during the Corona virus pandemic. This is because some countries take lockdown policies to protect their citizens and countries from Corona virus infection. According to data compiled by McKinsey in April 2020 yesterday, the decline in market value in the commercial aerospace industry reached $46 \%$. This decline is the highest among other industries. The majority are caused by flight cancellations, to the refund process.

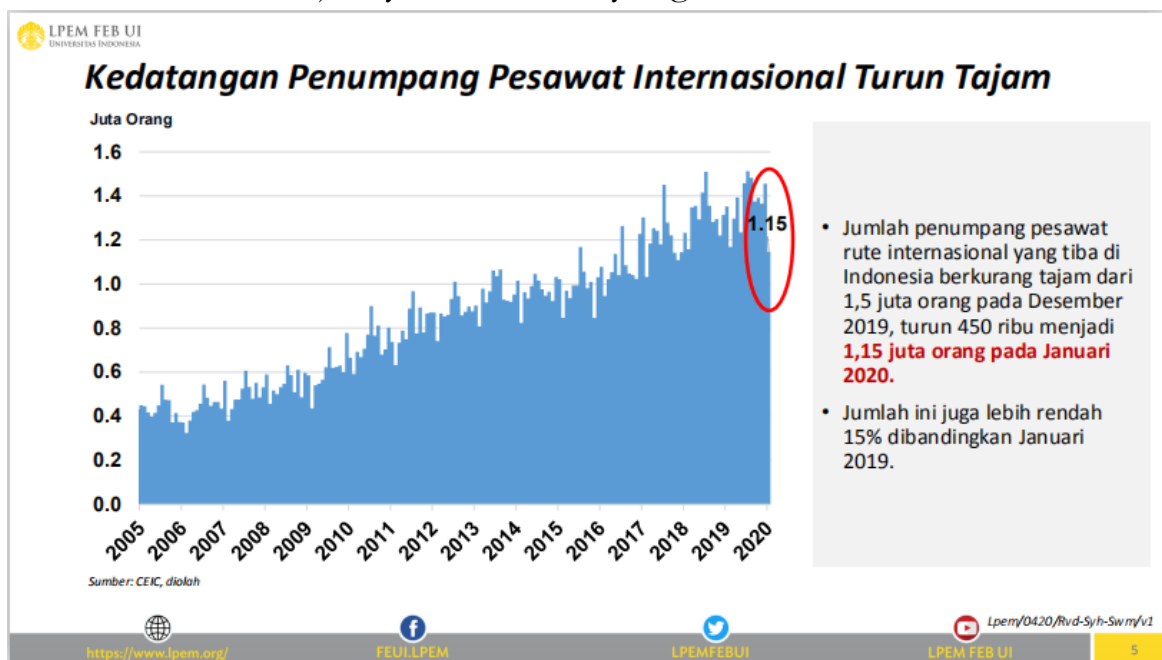

Source : CEIC, diolah (Pusat Kajian Iklim Usaha dan GVC - LPEM FEB UI, April 2020)

During the pandemic, people prefer to 'confine themselves' to their homes. Not only that, purchasing power in general has decreased. This condition makes many people decide to 'forget' for a while the bars and restaurants they used to visit. According to a recent survey, 46-48\% of people will eat out and hang out less in cafes because of the plague. This does not yet include the increasingly stringent PSBB, which asks that they only serve take away, and limit operating hours. The latest data in March 2020, about 50\% of people will limit entertainment activities during the 
pandemic. One such entertainment activity is watching a movie in the cinema. This condition forced many filmmakers to decide to postpone the launch of the latest film that was supposed to be aired in early 2020, for example Disney postponed the release of the film Mulan, and Universal Studios which delayed the screening of Fast and Furious 9. Sports events, especially sports with high TV ratings, like soccer, boxing, and others play an important role in the business world.

There are many business sectors involved in it, ranging from television broadcasting rights, sponsorship products, and others. During the pandemic, there were many sporting events which had to be postponed to be canceled, say, the Premier League, Serie A, La Liga, Bundesliga until Euro 2020. This condition made business players in the world of sports bite the fingers. Consumer electronics is not an essential requirement for most Indonesians, especially in the midst of the Corona virus pandemic. Nowadays people are more focused on maintaining cleanliness and buying basic necessities. This condition makes the value of shopping in the consumer electronics sector decline by more than $25 \%$. Some smartphone manufacturers even have to shift their production focus to sectors that are now more sought after by the public, such as air purifiers and others. The automotive sector must surrender to the Corona virus pandemic. Declining public purchasing power, and the decision of the finance company to choose to focus on resolving bad loans, made spending in the automotive sector declined dramatically. Just like electronics manufacturers, some automotive manufacturers have begun to 'spin' to other industrial sectors in order to survive.

For example the Lamborghini factory in Bologna that manufactures masks, to General Motors which produces ventilators and other medical devices. In the last few weeks, the wave of Termination of Employment (PHK) has increasingly spread in a number of sectors, ranging from manufacturing, tourism, transportation, trade, construction, and others. In addition, there are also some companies that are currently only able to pay half of their employees' salaries. CORE estimates that there will be an increase in open unemployment in the second quarter / 2020 with the worst case scenario reaching 9.35 million people. The impact of the COVID-19 pandemic is judged to be different for different business fields, different employment statuses, and different regions, both in terms of provincial locations and urban and rural locations. The impact of Covid-19 on the Indonesian economy today with various impacts that occur on the economy due to the Covid-19 pandemic that occurred at this time it is necessary to know the impacts that occur namely the difficulty in finding employment, difficult to meet the needs of daily life day and also do not have income to meet daily needs and also many hardships received from all sectors of the economy in all fields also felt the impact of Covid-19 (ㅂanoatubun, 2020).

\section{CONCLUSION}

Corona virus or often called Covid-19 is a deadly virus. This virus attacks the body's immune system and respiratory system which allows sufferers to experience general symptoms, which are the most common symptoms, fever, dry cough and fatigue. Other symptoms are discomfort and pain, sore throat, diarrhea, conjunctivitis (red eye) headache, loss of sense of smell or smell, rash on the skin, or discoloration of the fingers or toes. While the symptoms that are already serious are difficulty breathing or shortness of breath, chest pain or feeling depressed in the chest and loss of ability to speak or move. The impact of this virus was very widespread. In the field of education is very influential on the teaching and learning process, given that learning is forced to be assisted by online media (Purwanto, Pramono et al, 2020). The spread of welfare level that has 
not been evenly distributed, especially in Indonesia will have a negative impact on the smoothness of this learning, especially people who live in remote areas and are very limited in communication facilities.

In the business world, clearly the effect is very significant. The biggest impact is experienced in the hotel business, tourism, aviation and several other manufacturing companies Burhanuddin \& Abdi, 2020; Hanoatubun, 2020; Sihaloho, 2020). Manufacturing companies that employ large numbers of workers are affected by this virus. Most work shifts, laying off employees and even terminating work (FLE) to save performance and management going forward. Of course, everyone hopes that the virus will end soon. So that the implementation of New Normal is really in normal normal conditions. In the sense that people can interact normally without fear of contracting this deadly strange virus.

\section{REFERENCES}

Burhanuddin, C. I., \& Abdi, M. N. (2020). Krisis Ekonomi Global Dari Dampak Penyebaran Virus Corona (Covid-19). Jurnal Akuntansi Dan Manajemen (AKMEN), 17(1), 2020. https://doi.org/10.37476/akmen.v17i1.866

Carracedo, P., Puertas, R., \& Marti, L. (2021). Research lines on the impact of the COVID-19 pandemic on business. A text mining analysis. Journal of Business Research, 132, 586-593. https://doi.org/10.1016/j.jbusres.2020.11.043

Fabeil, N. F., Pazim, K. H., \& Langgat, J. (2020). The Impact of COVID-19 Pandemic Crisis on Micro-Enterprises: Entrepreneurs' Perspective on Business Continuity and Recovery Strategy. Journal of Economics and Business, 3(2), 1-9. https://papers.ssrn.com/sol3/papers.cfm?abstract_id=3612830

Hanoatubun, S. (2020). Dampak Covid - 19 terhadap Prekonomian Indonesia. EduPsyCouns: Journal of Education, Psychology and Counseling, 2(1), 146-153. https://ummaspul.ejournal.id/Edupsycouns/article/view/423

Hidayat, W. Y., Kakinaka, M., \& Miyamoto, H. (2012). Bank risk and non-interest income activities in the Indonesian banking industry. Journal of Asian Economics, 23(4), 335-343. https://doi.org/10.1016/j.asieco.2012.03.008

Hossain, M. (2021). The effect of the Covid-19 on sharing economy activities. Journal of Cleaner Production, 280, 124782. https://doi.org/10.1016/j.jclepro.2020.124782

Luo, C. (2021). Analyzing the impact of social networks and social behavior on electronic business during COVID-19 pandemic. Information Processing \& Management, 58(5), 102667. https://doi.org/10.1016/j.ipm.2021.102667

Meyer, B. H., Prescott, B., \& Sheng, X. S. (2021). The impact of the COVID-19 pandemic on business expectations. International Journal of Forecasting. https://doi.org/10.1016/j.ijforecast.2021.02.009

Nebolsina, E. (2021). The impact of the Covid-19 pandemic on the business interruption insurance demand in the United States. Heliyon, 7(11), e08357. https://doi.org/10.1016/j.heliyon.2021.e08357

Purwanto, A., Pramono, R., Asbari, M., Yun, C. C., Wijayanti, Laksmi Mayesti Putri, R. S., \& Santoso, P. B. (2020). Studi Eksploratif Dampak Pandemi COVID-19 Terhadap Proses Pembelajaran Online di Sekolah Dasar. EduPsyCouns: Journal of Education, Psychology and Counseling, 2(1), 1-12. https://ummaspul.e-journal.id/Edupsycouns/article/view/397

Rahmanti, A. R., Ningrum, D. N. A., Lazuardi, L., Yang, H.-C., \& Li, Y.-C. (2021). Social Media 
Data Analytics for Outbreak Risk Communication: Public Attention on the "New Normal" During the COVID-19 Pandemic in Indonesia. Computer Methods and Programs in Biomedicine, 205, 106083. https://doi.org/10.1016/j.cmpb.2021.106083

Sihaloho, E. D. (2020). Dampak Covid-19 Terhadap Perekonomian Indonesia. Center for Open Science. https://doi.org/http://dx.doi.org/10.13140/RG.2.2.14524.67205

Tanrivermiş, H. (2020). Possible impacts of COVID-19 outbreak on real estate sector and possible changes to adopt: A situation analysis and general assessment on Turkish perspective. Journal of Urban Management, 9(3), 263-269. https://doi.org/10.1016/j.jum.2020.08.005

Telukdarie, A., Munsamy, M., \& Mohlala, P. (2020). Analysis of the Impact of COVID-19 on the Food and Beverages Manufacturing Sector. Sustainability, 12(22), 9331. https://doi.org/10.3390/su12229331

Videon, T. M., Rosati, R. J., \& Landers, S. H. (2021). COVID-19 infection rates early in the pandemic among full time clinicians in a home health care and hospice organization. American Journal of Infection Control. https://doi.org/10.1016/j.ajic.2021.09.022 